\title{
METODE PELAYANAN INFORMASI PENSERTIPIKATAN TANAH NEGARA MELALUI PROGRAM PENDAFTARAN TANAH SISTEMATIS LENGKAP DI KANTOR PERTANAHAN KABUPATEN ENREKANG
}

\author{
Ismaya \\ M. Najib \\ Nurhidayat Muh. Said \\ Kantor Pertanahan Kabupaten Enrekang \\ ismaya.aya7@yahoo.co.id
}

\begin{abstract}
Abstrak: Tujuan Penelitian ini adalah untuk mengetahui dan mendeskripsikan sejauh mana efektifitas metode pelayanan informasi yang dilakukan oleh Kantor Pertanahan dalam menyampaikan informasi kepada masyarakat tentang pensertipikatan tanah Negara melalui program PTSL. Penelitian ini adalah penelitian deskriptif kualitatif, yang berlokasi di Kantor Pertanahan Kabupaten Enrekang dengan menggunakan pendekatan studi kasus. Penelitian ini tergolong kualitatif, data dikumpulkan dengan menggunakan metode observasi, metode wawancara, dan metode dokumentasi. Teknik pengolahan dan analisis data dilakukan dengan melalui tiga tahapan, yaitu reduksi data, penyajian data, dan penarikan kesimpulan.

Hasil dari penelitian ini menunjukkan bahwa Kantor Pertanahan Kabupaten Enrekang menggunakan metode informative communication. Tingkat efektivitas metode informative communication yang digunakan oleh Kantor Pertanahan kurang efektif, qaulan baliga (ucapan yang sampai pada lubuk hati orang yang diajak bicara) dan qaulan masyura (ucapan yang mudah, yakni mudah dicerna, mudah dimengerti, dan dipahami oleh komunikan) masih belum terlaksana dengan baik.

Sebagai implikasi, Kantor Pertanahan Kabupaten Enrekang sebagai penyedia informasi seharusnya jeli melihat kondisi pada masyarakat, dan bisa mencoba metode lain yang lebih efektif, jangan terpaku hanya kepada satu metode saja. Misalnya metode persuasive communication atau metode coersive/instructive communication agar informasi yang akan disampaikan betul-betul bisa sampai kepada masyarakat (komunikan) dan PTSL bisa berjalan sesuai apa yang diharapkan, sehingga bisa memberikan faedah dan manfaat kepada kedua bela pihak, baik bagi Kantor Pertanahan itu sendiri maupun bagi masyarakat.
\end{abstract}

\section{Kata Kunci: Layanan Informasi; Pensertipikatan Tanah}

\section{PENDAHULUAN}

Meningkatnya persaingan, tantangan dan tuntutan masyarakat akan pelayanan informasi yang berkualitas, mendorong Kantor Pertanahan untuk mempersiapkan diri agar tetap eksis dengan senantiasa mengupayakan perubahan kearah perbaikan. Salah satu bentuk pelayanan informasi yang diselenggarakan oleh pemerintah yaitu pendaftaran tanah yang dilaksanakan oleh Badan Pertanahan Nasional (BPN). 
Pendaftaran tanah yang dilakukan oleh Kantor Pertanahan akan menghasilkan sebuah produk akhir yaitu sertipikat. Sertipikat menurut Pasal 1 angka 20 PP Pendaftaran Tanah adalah surat tanda bukti hak (dokumen) sebagaimana dimaksud dalam Pasal 19 ayat (2) huruf c UUPA untuk hak atas tanah, hak pengelolaan, tanah wakaf, hak milik atas satuan rumah susun dan hak tanggung yang masing-masing sudah dibukukan dalam buku tanah yang bersangkutan. ${ }^{1}$ Sertipikat hak atas tanah berguna sebagai alat bukti kepemilikan suatu hak atas tanah bagi pemegang hak atas tanah yang bersangkutan. Ini berarti bahwa sertipikat atas tanah diterbitkan untuk kepentingan pemegang hak atas tanah tersebut (Pasal 31 ayat [1] PP Pendaftaran Tanah).

Kantor Pertanahan Kabupaten Enrekang terus mengembangkan kegiatan sertipikasi tanah Negara dengan salah satu melalui program Pendaftaran Tanah Sistematis Lengkap (PTSL). Pendaftaran tanah secara sistematik dilaksanakan atas prakasa pemerintah yang didasarkan pada suatu rencana kerja dan dilaksanakan diwilayah yang ditetapkan oleh Menteri. Yaitu kegiatan pendaftaran tanah untuk pertama kali yang dilakukan secara serentak yang meliputi semua obyek pendaftaran tanah yang belum didaftar dalam satu wilayah desa/kelurahan atau nama lainnya yang setingkat, dan juga termasuk pemetaan seluruh obyek pendaftaran tanah yang sudah terdaftar dalam rangka menghimpun dan menyediakan informasi yang lengkap mengenai bidang-bidang tanahnya.

Kantor Pertanahan Kabupaten Enrekang sebagai pelaksana program PTSL dituntut untuk memberikan pelayanan informasi yang akurat, sederhana (mudah difahami masyarakat) dan merata guna penerbitan sertipikat tanah Negara melalui program tersebut. Karena pensertipikatan tanah Negara tersebut sangat penting bagi masyarakat guna pengakuan hak atas kepemilikan sebidang tanah. Namun pada kenyataanya yang terjadi di lapangan, pelayanan informasi belum merata kepada seluruh masyarakat yang seharusnya mengetahui bahwa ada program pensertipikatan tanah Negara di desa mereka. Berdasarkan hasil observasi yang penulis telah lakukan, diperoleh gambaran bahwa pelayanan informasi belum berjalan maksimal sesuai yang diharapkan, hal ini dapat dilihat dari beberapa hasil observasi yang penulis temukan di lapangan, yaitu:

1. Masih ada masyarakat yang memiliki tanah di Desa/ Kelurahan tempat pelaksanaan PTSL yang tidak mengetahui bahwa ada program pensertipikatan tanah Negara melaui PTSL, ada juga yang sudah mengetahui tetapi kurang memahami prosedur.

2. Ada masyarakat yang sudah mengetahui dan sudah memahami prosedur tetapi mereka tidak memilki waktu yang banyak guna melengkapi berkas persyaratan pensertipikatan tanah Negara melaui PTSL.

Melihat masalah-masalah yang dihadapi masyarakat dalam proses sertipikasi tanah Negara, maka peneliti melakukan penelitian lebih lanjut tentang bagaiman tingkat efektivitas metode pelayanan informasi yang dilakukan oleh

\footnotetext{
${ }^{1}$ Pusat Bahasa Departemen Pedidikan Nasional Republik Indonesia, Kamus Besar Bahasa Indonesia (Jakarta: Depdikbud, 2012), h.212.
} 
Kantor Pertanahan Kabupaten Enrekang dalam pensertipikatan tanah Negara Melalui Program Pendaftaran Tanah Sistematis Lengkap (PTSL).

\section{KAJIAN TEORETIS}

Agar penyampaian informasi efektif, maka metode penyampaian perlu dirancang secara cermat sesuai dengan karakteristik komunikan maupun keadaan di lingkungan sosial yang bersangkutan. Jalaluddin Rakhmat mengatakan bahwa keberhasilan komunikasi sebagian ditentukan oleh kekuatan pesan. Namun sebagian besarnya tergantung pada cara penyampaiannya. ${ }^{2}$ Sebuah metode yang digunakan oleh informan dalam pelayanan informasi kepada komunikan harus efektif dan berpihak kepada komunikan. Metode lebih penting dari materi. Materi apapun yang disampaikan, jika menggunakan metode yang benar, maka akan dapat diterima dengan baik. Sebaliknya, materi yang telah dipersiapkan dengan matang, akan menjadi hampa, tanpa metode yang baik. ${ }^{3}$

Informasi dapat mengendalikan sikap dan perilaku komunikan. Agar proses komunikasi terlaksana secara efektif, maka perlu dipertimbangkan berbagai teknik sebagaimana diuraikan berikut ini:

Pesan satu sisi (one sided) ataukah dua sisi (two sided). Hal ini berkaitan dengan cara mengorganisasikan pesan. Organisasi pesan satu sisi, ialah suatu cara berkomunikasi dimana komunikator hanya menyampaikan pesan-pesan yang mendukung tujuan komunikasi saja. Sedangkan pesan dua sisi, berarti selain pesan yang bersifat mendukung, disampaikan pula counter argument, sehingga komunikan diharapkan menganalisis sendiri atas pesan tersebut. Apakah dalam menyampaikan pesan itu diorganisasikan secara satu sisi atau dua sisi, tentulah harus disesuaikan dengan karakteristik.

Sedangkan pesan dua sisi, secara teoritis lebih efektif dikarenakan pada karakteristik pola komunikasi sebagai berikut:

a. Pada awalnya komunikan tidak sepakat dengan komunikator.

b. Komunikan menyadari argument yang berlawanan sebelum penyajian pesan, atau sewaktu pesan akan disampaikan.

c. Komunikan memiliki latar pendidikan yang baik (tinggi).

d. Komunikator menginginkan kejujuran, keterbukaan, serta objektif dalam pesannya dan tidak terlalu menghiraukan hasil komunikasi

Dalam menyampaikan pesan, seorang komunikator tidak perlu terlalu ambisi untuk mencapai hasil segera. Untuk dapat mempengaruhi komunikan secara efektif, penyampaian pesan perlu memperhatikan langkah-langkah:

\footnotetext{
${ }^{2}$ Jalaluddin Rakhmat, Psikologi Komunikasi (Bandung: PT. Remaja Rosdakarya, 1993), h. 268 .

${ }^{3}$ Suranto AW, Komunikasi Efektif Untuk Mendukung Kinerja Perkantoran, 2006, (http://www.google.com/komunikasi/20018).
} 
a. Attention (perhatian). Artinya bahwa pesannya harus dirancang dan disampaikan sedemikian rupa sehingga dapat menumbuhkan perhatian dari komunikan.

b. Need (kebutuhan). Artinya bahwa komunikator kemudian berusaha meyakinkan komunikan bahwa pesan yang disampaikan itu penting bagi komunikan.

c. Satisfaction (pemuasan), dalam hal ini komunikator memberikan bukti bahwa yang disampaikan adalah benar.

d. Visualization (visualisasi) komunikator memberikan bukti-bukti lebih konkret sehingga komunikan bisa turut menyaksikan.

e. Action (tindakan), komunikator mendorong agar komunikan bertindak positif yaitu melaksanakan pesan dari komunikator tersebut.

Metode penyampaian informasi memang berpengaruh terhadap keefektifan proses komunikasi. Metode penyampaian yang baik, akan memudahkan komunikan dalam menerima dan memahaminya. Metode layanan informasi baru dikatakan efektif jika antara masing-masing pihak (komunikator dan komunikan) mengerti bahasa yang digunakan dan paham terhadap apa yang dibicarakan.

Gaya bicara dan pilihan kata dalam berkomunikasi dengan orang awam tentu harus dibedakan dengan saat berkomunikasi dengan kalangan cendekiawan. Berbicara di depan anak TK tentu harus tidak sama dengan saat berbicara di depan mahasiswa. Dalam konteks akademis, kita dituntut menggunakan bahasa akademis. Saat berkomunikasi di media massa, gunakanlah bahasa jurnalistik sebagai bahasa komunikasi massa (language of mass communication). ${ }^{4}$

Alo Liliweri mengemukakan bahwa metode komunikasi ada 3, yaitu: informative communication, persuasive communication, coersive/instructive communication. ${ }^{5}$

\section{a. Informative communication}

Informative communication lebih sering digunakan sebagai sarana bercerita tentang suatu aktivitas atau peristiwa, mungkin sekali dianggap kecil namun luput dari perhatian publik. Barangkali aktivitas keseharian yang kecil dan tidak berarti yang dilakukan secara individu atau kelompok. ${ }^{6}$

Berkaitan dengan komunikasi yang bersifat informatif tujuan utamanya adalah mengurangi keragu-raguan dalam hal pengambilan keputusan. Dengan adanya informasi yang diperoleh akan dapat membantu mengurangi ketidakpastian. Informasi yang dicari manusia dalam kebanyakan komunikasinya adalah "isi"nya. Isi komunikasi itu akan membantunya menyusun dan mengorganisasi beberapa aspek lingkungannya yang relevan dengan situasi di

${ }^{4}$ http://romeltea.com/komunikasi-islam-makna-dan-prinsip/ (akses pada 21 September 2018)

${ }^{5}$ Alo Liliweri, Komunikasi, h. 273.

${ }^{6}$ Alo Liliweri, Komunikasi, h. 282. 
mana dia harus bertindak. Akibatnya, informasi yang diperolehnya akan memudahkan ia membuat keputusan. Informasi yang diperoleh dari adanya hubungan komunikasi yang dilakukan akan mengurangi ketidakpastian. ${ }^{7}$

\section{b. Persuasive communication.}

Komunikasi yang bersifat persuasif dimaksudkan untuk mengarahkan pemakai (penerima pesan; komunikan) merubah beberapa gambaran atau kesan yang ada dikepalanya dan mungkin nantinya merubah tingkah lakunya. ${ }^{8}$ Untuk tujuan ini, dia mungkin memilih informasi yang cocok dengan kemauannya dan menyampaikannya kepada komunikan karena itulah yang dianggap terbaik. Persuasive communication dalam konteks komunikasi interpersonal, maksudnya adalah ketika seseorang mencoba membujuk orang lain supaya berubah, baik dalam kepercayaannya, sikapnya, atau perilakunya. Contohnya misalnya ketika Anda atau kita membujuk orang tua kita dengan maksud supaya mereka memberi kita uang, atau meluluskan keinginan-keinginan kita. Sedangkan persuasi dalam konteks komunikasi massa, maksudnya adalah ketika seseorang berusaha membujuk sekelompok orang agar mereka bisa berubah, baik dalam kepercayaannya, sikapnya, maupun perilakunya. Contohnya seperti orang-orang yang memiliki kharisma berpidato kepada sekelompok massa dengan tujuan untuk membujuk mereka agar mau mendukung kepentingan-kepentingannya. ${ }^{9}$

\section{c. Coersive/instructive communication}

Komunikasi instruktif atau koersif adalah teknik komunikasi berupa perintah, ancaman, sanksi dan lain-lain yang bersifat paksaan, sehingga orangorang yang dijadikan sasaran (komunikan) melakukannya secara terpaksa, biasanya teknik komunikasi seperti ini bersifat fear arousing, yang bersifat menakut-nakuti atau menggambarkan resiko yang buruk. Serta tidak luput dari sifat red-herring, yaitu interes atau muatan kepentingan untuk meraih kemenangan dalam suatu konflik, perdebatan dengan menepis argumentasi yang lemah kemudian dijadikan untuk menyerang lawan. Bagi seorang diplomat atau tokoh politik teknik tersebut menjadi senjata andalan dan sangat penting untuk mempertahankan diri atau menyerang secara diplomatis. ${ }^{10}$

Jika dipahami lebih jauh komunikasi Nabi Saw. baik di dalam keluarga maupun dengan sahabatnya, ternyata ketiga metode komunikasi sebagaimana di atas dipraktekkan dengan melihat situasi dan kondisinya. Salah satu contoh hadis yang terkait dengan metode komunikasi di atas adalah:

\footnotetext{
${ }^{7}$ Abdillah Hanafi, Memahami Komunikasi Antar Manusia (Surabaya: Usaha Nasional, tt.), h. 45 .

${ }^{8}$ Abdillah Hanafi, Memahami Komunikasi Antar Manusia, h. 54.

${ }^{9} \mathrm{http}: / /$ www.uky.edu/ drlane/capstone/persuasion/, diakses pada tanggal 3 Oktober 2018.

${ }^{10} \mathrm{http} / / /$ situliatsitucoment.blogspot.com/2010/02/informative-communicationkomunikasi.html, diakses pada tanggal 3 Oktober 2018.
} 
Dari Ummi Salamah berkata, aku mendengar Rasulullah Saw. bersabda, "Barangsiapa yang mendapatkan musibah kemudian mengucapkan "Sesungguhnya semua datang dari Allah dan akan kembali kepada-Nya. Ya Allah, berilah aku pahala atas musibah ini dan berikanlah ganti yang lebih baik". Ummu Salamah berkata lagi, "Saat suamiku meninggal, aku mengucapkan seperti yang Rasul ullah ajarkan padaku dan kemudian Allah menggantikan aku yang lebih baik, yaitu (aku menikah dengan) Rasulullah sallallahu 'alaihi wa sallam. (HR. Muslim).

Aisyah radhiyallahu anha berkata Rasullullah sallallahu 'alaihi wa sallam bersabda, "Janganlah menghina orang yang sudah meninggal dunia, karena mereka telah melakukan apa yang dapat mereka perbuat (HR. Imam Bukhari).

Abu Hurairah r.a. berkata, dibawa ke hadapan Rasulullah Saw. seorang yang tertangkap telah mabuk (minum khamar). Rasulullah Saw. berkata: "hukumlah dia (pukullah)". Maka di antara kami ada yang memukul dengan tangannya, dengan sandalnya, juga ada yang dengan kain. Ketika telah selesai pergilah orang itu, namun ada seorang sahabat yang berkata padanya, "Semoga Allah menghinakan kamu!!!”. Mendengar itu rasulullah berkata, "Janganlah kau berkata seperti itu padanya. Jangan kamu membantu syaitan (dalam menyesatkan orang itu)”. (HR. Imam Bukhari).

Berikut ini cara berkomunikasi atau penyampaian informasi yang baik menurut al-quran atau "komunikasi islam":

1. Qaulan Sadida: Perkataan yang benar sebagaimana dala QS an- Nisa'/4: 9:

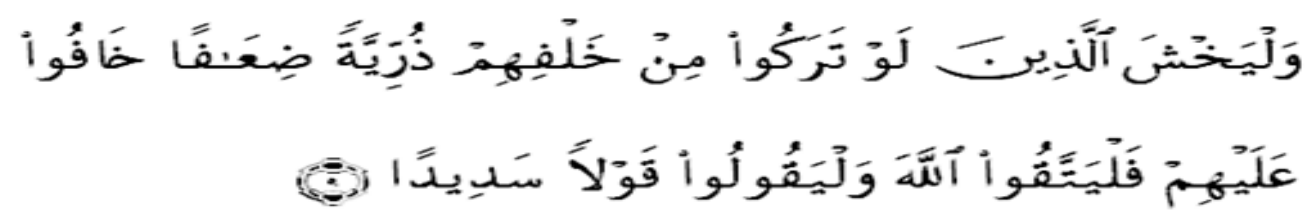

Terjemahnya:

"Dan hendaklah takut kepada Allah orang-orang yang seandainya meninggalkan dibelakang mereka anak-anak yang lemah, yang mereka khawatir terhadap (kesejahteraan) mereka. Oleh sebab itu hendaklah mereka bertakwa kepada Allah dan hendaklah mereka mengucapkan Qaulan Sadida - perkataan yang benar". ${ }^{11}$

Dalam Tafsir Al-Qurtubi dijelaskan, as-sadid yaitu perkataan yang bijaksana dan perkataan yang benar. Dalam beromunikasi (berbicara) harus 78.

${ }^{11}$ Kementerian Agama RI, Al-Qur'an dan Terjemahnya (Bogor, Dharma Art, 2007), h. 
menginformasikan atau menyampaikan kebenaran, faktual, hal yang benar saja, jujur, tidak berbohong, juga tidak merekayasa atau memanipulasi fakta. "Dan jauhilah perkataan-perkataan dusta". 12 "Katakanlah kebenaran walaupun pahit rasanya" (HR Ibnu Hibban).

\section{Qaulan Baligha - Berdampak, Efektif}

Metode layanan informasi harus bersifat Qaulan Baligha (tepat sasaran, komunikatif, to the point, mudah dimengerti). Sebagaimana dalam QS an- Nisa'/ 4: 63:

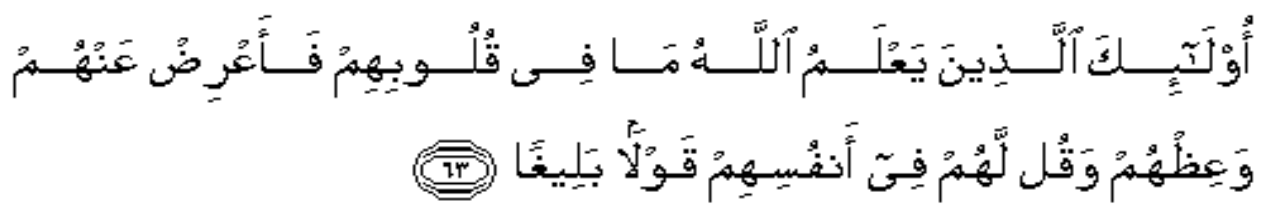

Terjemahnya:

"Mereka itu adalah orang-orang yang Allah mengetahui apa yang di dalam hati mereka. karena itu berpalinglah kamu dari mereka, dan berilah mereka pelajaran, dan katakanlah kepada mereka Qaulan Baligha - perkataan yang berbekas pada jiwa mereka". 13

Ayat di atas menginformasikan kepada kita tentang kebusukan hati kaum munafik. Dimana mereka tidak akan pernah patuh kepada Rasulullah Saw sekalipun mereka bersumpah atas nama Allah Swt, karena apa yang mereka kerjakan semata-mata hanya menghendaki kebaikan. Walaupun demikian, Allah Swt melarang Rasulullah Saw untuk menghukum mereka secara fisik (pengertian dari "berpalinglah dari mereka"), akan tetapi Allah Swt menganjurkan untuk memberi nasehat berupa ancaman bahwa kekejian mereka akan mengundang azab Allah Swt. Nasehat tersebut tentunya dengan qaulan baliga. Kata baliga merupakan bentuk masdar dari balaga,yang berarti sampai, atau sampainya sesuatu kepada sesuatu yang lain. ${ }^{14}$

Dalam hal ini, para ahli balagah (ahli sastra) - sebagaimana dikutip oleh Quraish Shihab - mengatakan bahwa suatu pesan atau perkataan baru dianggap baliga apabila memenuhi beberapa kriteria tertentu. Kriteria-kriteria dimaksud adalah sebagai berikut ini:

1. Penggunaan kalimat mencakup seluruh pesan yang ingin disampaikan.

2. Kalimatnya tidak berulang-ulang, dan juga tidak terlalu pendek/singkat sehingga pengertiannya menjadi kabur.

3. Kosa kata yang digunakan tidak terkesan asing bagi komunikan.

15 .

${ }^{12}$ Kementerian Agama RI, Al-Qur'an dan Terjemahnya (Bogor, Dharma Art, 2007), h.

${ }^{13}$ Kementerian Agama RI, Al-Qur'an dan Terjemahnya (Bogor, Dharma Art, 2007), h. 88.

${ }^{14}$ Ahmad Warson Munawwir, Kamus Al-Munawwir (Edisi II, Cet. XXV; Surabaya: Pustaka Progressif, 2002), h. 107. 
4. Kesesuaian kandungan dan gaya bahasa dengan komunikan.

5. Tata bahasanya tepat dan jelas. ${ }^{15}$

Hamka menyebutkan bahwa ungkapan qaulan baligha bermakna ucapan yang sampai pada lubuk hati orang yang diajak bicara, yaitu kata-kata yang fashahat dan balaghah (fasih dan tepat); kata-kata yang membekas pada hati sanubari. Kata-kata seperti ini tentunya keluar dari lubuk hati sanubari orang yang mengucapkannya. Sementara al-Buruswi memaknai qaulan baligha dari segi cara mengungkapkannya. Lebih lanjut al-Maraghi mengaitkan qaulan baligha dengan arti tabligh sebagai salah satu sifat Rasul (Tabligh dan baligh berasal dari akar kata yang sama yaitu balagha), yaitu Nabi Muhammad diberi tugas untuk menyampaikan peringatan kepada umatnya dengan perkataan yang menyentuh hati mereka. Senada dengan itu, Katsir menyatakan makna kalimat ini, yaitu menasihati dengan ungkapan yang menyentuh sehingga mereka berhenti dari perbuatan salah yang selama ini mereka lakukan. Dari segi lain Asidiqi memaknai qaulan baligha dari segi gaya pengungkapan, yaitu perkataan yang membuat orang lain terkesan atau mengesankan orang yang diajak bicara. ${ }^{16}$

Dari sudut ilmu komunikasi Rahmat mengartikan ungkapan qaulan baligha sebagai ucapan yang fasih, jelas maknanya, tenang, tepat mengungkapkan apa yang dikehendaki, karena itu qaulan baligha diterjemahkan sebagai komunikasi yang efektif. Efektivitas komunikasi terjadi apabila komunikator menyesuaikan pembicaraannya dengan sifat-sifat khalayak yang dihadapinya. Qaulan baligha mengandung arti pula bahwa komunikator menyentuh khalayaknya pada hati dan otak sekaligus, sehingga komunikasi dapat terjadi secara tepat dan efektif. ${ }^{17}$

Dengan demikian, kata baliga merupakan salah satu teknik berbicara atau penyampaian pesan dengan menggunakan ungkapan atau kalimat yang tepat sasaran, jelas dan tujuannya tercapai, sehingga komunikasinya menjadi efektif. Dengan kata lain, baliga merupakan suatu kalimat yang singkat, tepat, padat dan jelas.

3. Qaulan Ma'rufa: Kata-Kata yang Baik sebagaimana dalam QS an- Nisa'/ 4: 5:

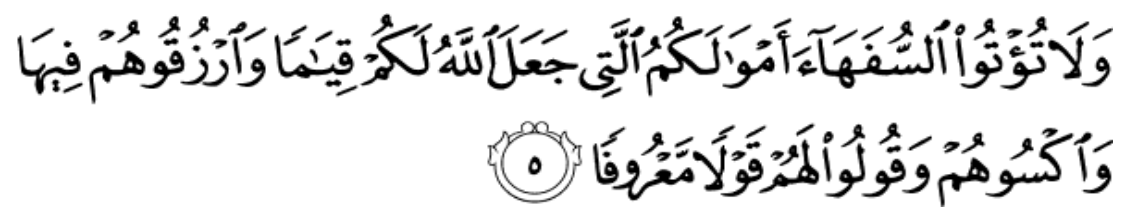

Terjemahnya:

"Dan janganlah kamu serahkan kepada orang-orang yang belum sempurna akalnya, harta (mereka yang ada dalam kekuasaanmu) yang dijadikan Allah sebagai pokok kehidupan. berilah mereka belanja dan

\footnotetext{
${ }^{15}$ Quraish Shihab, Tafsir al-Misbah (Jilid II; Jakarta: Lentera Hati, 2000), h. 468.

${ }^{16}$ http://el-syahida.blogspot.com/2014/06/qoulan-baliigho-dalam-al-quran.html (akses pada tanggal 22 September 2018)

${ }^{17}$ http://el-syahida.blogspot.com/2014/06/qoulan-baliigho-dalam-al-quran.html (akses pada tanggal 22 September 2018)
} 
Metode Pelayanan Informasi Pensertipikatan Tanah Negara melalui Program Pendaftaran Tanah Sistematis Lengkap di Kantor Pertanahan Kabupaten Enrekang

pakaian (dari hasil harta itu) dan ucapkanlah kepada mereka Qaulan Ma'rufa-kata-kata yang baik."18

QS an- Nisa'/4: 8:

Terjemahnya:

"Dan apabila sewaktu pembagian itu hadir kerabat, anak yatim dan orang miskin, Maka berilah mereka dari harta itu (sekadarnya) dan ucapkanlah kepada mereka Qaulan Ma'rufa -perkataan yang baik". ${ }^{19}$

QS al-Baqarah/2: 235:

Terjemahnya:

"Dan tidak ada dosa bagi kamu meminang wanita-wanita itu dengan sindiran atau kamu Menyembunyikan (keinginan mengawini mereka) dalam hatimu. Allah mengetahui bahwa kamu akan menyebut-nyebut mereka, dalam pada itu janganlah kamu Mengadakan janji kawin dengan mereka secara rahasia, kecuali sekadar mengucapkan (kepada mereka) Qaulan Ma'rufa - perkataan yang baik...". ${ }^{20}$

QS al-Baqarah/ 2: 263:

Terjemahnya:

"Qulan Ma'rufa -perkataan yang baik-dan pemberian maaf lebih baik dari sedekah yang diiringi dengan sesuatu yang menyakitkan (perasaan si penerima). Allah Maha Kaya lagi Maha Penyantun.".'21

QS al-Ahzab/33: 32:

Terjemahnya:

"Hai istri-istri Nabi, kamu sekalian tidaklah seperti wanita yang lain, jika kamu bertakwa. Maka janganlah kamu tunduk dalam berbicara sehingga berkeinginanlah orang yang ada penyakit dalam hatinya] dan ucapkanlah Qaulan Ma'rufa - perkataan yang baik. ". ${ }^{22}$

Prinsip komunikasi Islam Qaulan Ma'rufa artinya perkataan yang baik, ungkapan yang pantas, santun, menggunakan sindiran (tidak kasar), dan tidak menyakitkan atau menyinggung perasaan. Qaulan Ma'rufa juga bermakna pembicaraan yang bermanfaat dan menimbulkan kebaikan (maslahat). Dalam Tafsir Al-Qurtubi dijelaskan, Qaulan Ma'rufa yaitu melembutkan kata-kata dan menepati janji.

\footnotetext{
77.

${ }^{19}$ Kementerian Agama RI, Al-Qur'an dan Terjemahnya (Bogor, Dharma Art, 2007), h.

78.

${ }^{20}$ Kementerian Agama RI, Al-Qur'an dan Terjemahnya (Bogor, Dharma Art, 2007), h.

38.

${ }^{21}$ Kementerian Agama RI, Al-Qur'an dan Terjemahnya (Bogor, Dharma Art, 2007), h.

44.

${ }^{22}$ Kementerian Agama RI, Al-Qur'an dan Terjemahnya (Bogor, Dharma Art, 2007), h. 422 .
}

${ }^{18}$ Kementerian Agama RI, Al-Qur'an dan Terjemahnya (Bogor, Dharma Art, 2007), h. 
4. Qaulan Karima - Ucapan yang Mulia sebagaimana dalam QS al-Isra'/ 17: 23:

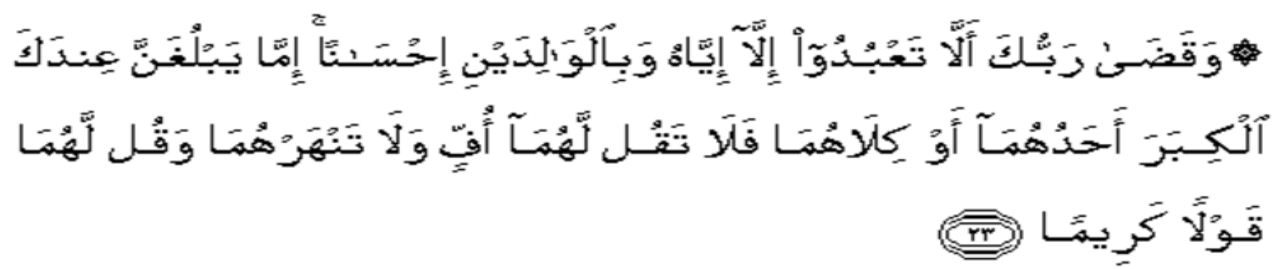

Terjemahnya:

"Dan Tuhanmu telah memerintahkan supaya kamu jangan menyembah selain Dia dan hendaklah kamu berbuat baik pada kedua orangtuamu dengan sebaik-baiknya. Jika salah seorang di antara keduanya atau kedua duanya sampai berumur lanjut dalam pemeliharaanmu, sekali kali janganlah kamu mengatakan kepada keduanya perkatan 'ah' dan kamu janganlah membentak mereka dan ucapkanlah kepada mereka Qaulan Karima-ucapan yang mulia, ${ }^{, 23}$

Qaulan Karima adalah perkataan yang mulia, dibarengi dengan rasa hormat dan mengagungkan, enak didengar, lemah-lembut, dan bertatakrama. Dalam ayat tersebut perkataan yang mulia wajib dilakukan saat berbicara dengan kedua orangtua. Kita dilarang membentak mereka atau mengucapkan kata-kata yang sekiranya menyakiti hati mereka.

Qaulan Karima harus digunakan khususnya saat berkomunikasi dengan kedua orangtua atau orang yang harus kita hormati. Qaulan Karima adalah "katakata yang hormat, sopan, lemah lembut di hadapan mereka" (Ibnu Katsir).

5. Qulan Layina - Lemah-Lembut sebagaimana dalam QS ta-Ha/ 20: 44:

Terjemahnya:

"Maka berbicaralah kamu berdua kepadanya dengan Qulan Layina kata-kata yang lemah-lembut, mudah-mudahan dia sadar atau takut". ${ }^{24}$

Qaulan Layina berarti pembicaraan yang lemah-lembut, dengan suara yang enak didengar, dan penuh keramahan, sehingga dapat menyentuh hati. Dalam Tafsir Ibnu Katsir disebutkan, yang dimaksud layina ialah kata kata sindiran, bukan dengan kata kata terus terang atau lugas, apalagi kasar.

Ayat di atas adalah perintah Allah SWT kepada Nabi Musa dan Harun agar berbicara lemah-lembut, tidak kasar, kepada Fir'aun. Dengan Qaulan Layina, hati komunikan (orang yang diajak berkomunikasi) akan merasa tersentuh dan jiwanya tergerak untuk menerima pesan komunikasi kita.

Menurut Tafsir Al-Qurtubi, ayat ini merekomendasikan untuk memberi peringatan dan melarang sesuatu yang munkar dengan cara yang simpatik melalui

\footnotetext{
${ }^{23}$ Kementerian Agama RI, Al-Qur'an dan Terjemahnya (Bogor, Dharma Art, 2007), h. 284.

${ }^{24}$ Kementerian Agama RI, Al-Qur'an dan Terjemahnya (Bogor, Dharma Art, 2007), h. 314.
} 
ungkapan atau kata-kata yang baik dan hendaknya hal itu dilakukan dengan menggunakan perkataan yang lemah lembut, lebih-lebih jika hal itu dilakukan terhadap penguasa atau orang-orang yang berpangkat.

6. Qaulan Maysura - Mudah Dipahami sebagaimana dala QS al-Isra'/ 17: 28:

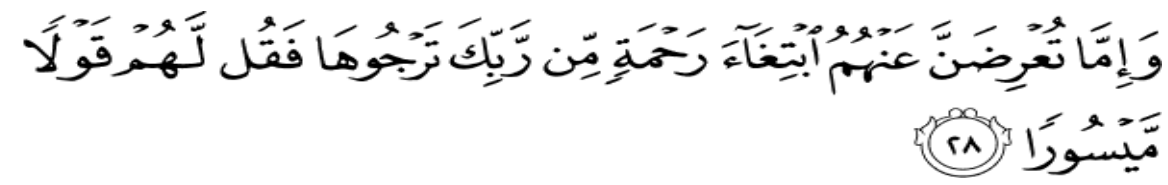

Terjemahnya:

"Dan jika kamu berpaling dari mereka untuk memperoleh rahmat dari Tuhannya yang kamu harapkan, maka katakanlah kepada mereka Qaulan Maysura-ucapan yang mudah". ${ }^{25}$

Qaulan Maysura (Maisuran) bermakna ucapan yang mudah, yakni mudah dicerna, mudah dimengerti, dan dipahami oleh komunikan. Makna lainnya adalah kata-kata yang menyenangkan atau berisi hal-hal yang menggembirakan.

Menurut Tafsir Ibnu Katsir, Qaulan Maysura adalah ucapan-ucapan yang pantas, halus, dan lembut. Menurut Tafsir Al-Azhar, ia adalah kata-kata yang menyenangkan. Karena kadang-kadang kata-kata yang halus dan berbudi lagi membuat orang senang dan lega, lebih berharga daripada uang berbilang.

Berdasarkan beberapa pendapat sebelumnya maka peneliti dapat menyimpulkan bahwa metode layanan informasi adalah cara-cara atau langkah yang digunakan atau dilakukan oleh informan guna menyampaikan berbagai informasi (informasi verbal maupun non verbal) agar isi dan tujuan informasi dapat diterima dan difahami oleh penerima informasi, sehingga tujuan dapat tercapai. Informan dalam menyampaikan informasi kepada penerima informasi dapat melakukan beberapa metode, yaitu: ${ }^{26}$ Sosialisasi/ ceramah, Face to face, spanduk, brosur, telepon/ SMS, iklan, dan lain-lain.

\section{METODOLOGI PENELITIAN}

Jenis penelitian ini adalah penelitian deskriptif kualitatif. Penelitian ini berlokasi di Kantor Pertanahan Kabupaten Erekang. Pendekatan dalam penelitian ini adalah pendekatan studi kasus. Sumber data ada dua, yaitu sumber data primer dan sumber data sekunder. Untuk memperoleh data yang sesuai permasalahan penelitian ini maka teknik yang penulis gunakan dalam pengumpulan data, yaitu melalui langkah-langkah sebagai berikut: a) Observasi; b) Wawanacara (Interview); dan c) Dokumentasi.

Untuk menetapkan keabsahan data diperlukan teknik pemeriksaan. Uji keabsahan data dalam penelitian kualitatif meliputi uji credibility (validitas internal), transferability (validitas eksternal), dependability (reliabilitas), dan 285 .

${ }^{25}$ Kementerian Agama RI, Al-Qur'an dan Terjemahnya (Bogor, Dharma Art, 2007), h.

${ }^{26}$ http://ganiasmoro.blogspot.co.id/2012/03/definisi-macam-macam-metode_2144.html, (akses 22 Agustus 2018). 
confirmability (obyektifitas). ${ }^{27}$ Dalam penelitian ini, pengujian keabsahan data yang digunakan adalah uji kredibilitas yaitu dilakukam dengan menggunakan teknik triangulasi dan member check.

\section{HASIL PENELITIAN DAN PEMBAHASAN}

Metode merupakan cara. Jadi metode dalam layanan informasi merupakan cara dalam menyampaikan informasi kepada khalayak. Seperti telah dijelaskan sebelumnya bahwa metode merupakan hal yang sangat penting dalam penyampaian informasi. Dalam menyampaikan informasi, informan harus pandai melihat kepada siapa mereka akan berbicara. Karena daya tangkap dan daya faham orang itu berbeda beda. Latar belakang pendidikan dan lingkungan komunikan sangat berpengaruh dalam hal menerima informasi. Informasi dikatakan berhasil jika isi dari pesan itu tersampaikan dengan baik.

Peneliti melakukan berbagai kegiatan penelitian untuk mengetahui bagaimana tingkat efektivitas motede layanan informasi yang digunakan oleh Kantor Pertanahan Kabupaten Enrekang dalam melaksanakan sertipikasi tanah Negara melaui PTSL dan mengkaitkannya dengan fakta dilapangan. Efektivitas adalah suatu variabel yang menyatakan seberapa jauh target (kuantitas, kualitas dan waktu) yang telah dicapai oleh manajemen, yang mana target tersebut sudah ditentukan terlebih dahulu.

Setelah melakukan survey dan penelitian serta wawancara dengan berbagai pihak atau dengan para informan, peneliti menemukan berbagai informasi, tanggapan dan permasalahan mengenai efektivitas metode layanan informasi yang digunakan oleh Kantor Pertanahan Kabupaten Enrekang dalam melaksanakan sertipikasi tanah Negara melaui PTSL.

Peneliti melakukan wawancara dengan Bapak Saiful, untuk mengetahui jenis metode pelayanan informasi yang dilakukan, berikut hasil wawancaranya:

"Metode yang kami gunakan dalam memberikan informasi tentang PTSL yaitu pertama dengan memanggil Kepala Desa Lebang beserta salah seorang stafnya dan para Kepala Dusun yang ada di Desa Lebang untuk datang di kantor. Saya beserta Bapak Asmin dan Bapak Syafaruddin memberikan pengarahan kepada mereka tentang apa itu PTSL, apa manfaat bagi mereka dan seluruh masyarakat yang ada di desa Lebang. Kami juga menjelaskan tentang tata cara pelaksanaan PTSL mulai dari pengisian blangko permohonan sampai dengan kelengkapan berkasnya. Setelah beberapa hari kemudian, kami beserta Kepala kantor, Ketua Fisik, Ketua Yuridis dan beberapa teman dari kantor pertanahan menuju Desa Lebang untuk mengadakan sosialisasi yang dipusatkan di aula kantor Desa Lebang. Kami juga memasang spanduk di beberapa titik di desa Lebang". 28

${ }^{27}$ Sugiyono, Model Penelitian Kuantitatif, Kualitatif, R \& D, h.366.

${ }^{28}$ Saiful (49 tahun), Ketua Adjukasi PTSL, Wawancara, Enrekang, 04 Oktober 2018. 
Metode Pelayanan Informasi Pensertipikatan Tanah Negara melalui Program Pendaftaran Tanah Sistematis Lengkap di Kantor Pertanahan Kabupaten Enrekang

Terkait alasan pemilihan metode pelayanan informasi, peneliti melakukan wawancara dengan Bapak Asmin Mustamin:

"Iya betul, kami melakukan sosialisasi dulu di Desa Lebang sekitar akhir bulan Februari. Kami sengaja memilih cara itu, karena kami tahu bahwa penduduk desa itu kebanyakan hanya mau mengetahui sesuatu dari hasil mendengar. Oleh karena itu kami tidak melakukan pemberitahuan lewat surat kepada masyarakat, karena hanya ada beberapa dari mereka yang mau membaca". 29

Untuk mengetahui sejauh mana metode yang mereka gunakan sudah berjalan maksimal, maka pada hari itu juga peneliti melakukan wawancara dengan Bapak Syafaruddin, hasil wawancaranya seperti ini:

"Pada Bulan Februari lalu, saya beserta beberapa orang teman dari kantor pertanahan mengadakan sosialisasi di desa Lebang. Dan pada saat itu, sosialisasi dipusatkan di kantor desa Lebang. Namun kami merasa bahwa sosialisasi yang kami adakan saat itu kurang maksimal, karena dari berapa Kepala Keluarga yang ada di Desa Lebang, hanya beberapa orang yang hadir. Entah itu karena Kepala Desa beserta Staf Desanya kurang maksimal dalam memberikan informasi kepada masyarakatnya, ataukah memang masyarakatnya yang tidak ada perhatian untuk hal itu', ${ }^{30}$

Setiap pekerjaan pasti ada kendalanya. Begitu juga dengan sosialisasi yang dilakukan oleh kantor pertanahan Kabupaten Enrekang dalam menyampaikan informasi tentang PTSL kepada masyarakat. Untuk mengetahui kendala apa yang dihadapi, peneliti melakukan wawancara dengan Bapak Muhammad Asdar:

"Ya itu dia kendalanya, ketika kami melakukan sosialisasi hanya beberapa masyarakat yang hadir. Sehingga kami merasa sedikit kecewa saat itu. Menurut Kepala Desa sih sudah disampaikan kepada masyarakat, tetapi mungkin mereka lebih memilih untuk pergi ke kebun mereka bekerja daripada hadir mendengarkan sosialisasi itu. Kesadaran masyarakat memang masih sangat kurang untuk hal ini"."31

Peneliti kembali melakukan wawancara dengan Bapak Saiful untuk mengetahui langkah yang diambil oleh kantor pertanahan Kabupaten Enrekang dalam meminimalisir kendala yang terjadi:

"Sekitar awal bulan April, kami turun lagi ke Desa Lebang. Kami kembali mengadakan sosialisasi kepada masyarakat. Tetapi saat itu, kami adakan di bawah kolong rumah salah seorang Tokoh Masyarakat. Kami sengaja memilih tempat itu karena kami merasa bahwa tempat itu lebih luas dan

\footnotetext{
${ }^{29}$ Asmin Mustamin (38 tahun), Ketua Yuridis PTSL, Wawancara, Enrekang 08 Oktober 2018 .

${ }^{30}$ Syafaruddin (56 tahun), Ketua Fisik PTSL, Wawancara, Enrekang, 08 Oktober 2018.

${ }^{31}$ Muhammad Asdar (49 tahun), Penanggungjawab PTSL. Wawancara, Enrekang, 09 Oktober 2018.
} 
lebih gampang terjangkau oleh masyarakat yang bertempat tinggal jauh dari kantor Desa. Namun lagi-lagi yang hadir hanya sekitaran 20\% (dua puluh persen) dari jumlah masyarakat yang ada di Desa Lebang. Sehingga kami merasa sedikit kecewa terhadap masyarakat yang ada di sana. "32

Kemudian peneliti melakukan lagi wawancara dengan Bapak Syafaruddin, hal senada diungkapkan:

"Iya, kami kembali turun sekitar awal bulan April, dan kami sengaja memutuskan untuk shalat Duhur di sana. Karena kami fikir, mungkin saja di jam jam itu masyarakat sudah bisa hadir karena mereka sudah pulang dari kebun atau sawah mereka. Tapi ternyata tetap saja sama, hanya beberapa orang yang hadir saat itu,33

Untuk mengetahui lebih jauh tentang respon pihak desa terhadap metode sosialisasi yang digunakan oleh kantor pertanahan, maka peneliti menuju Desa Lebang dan mengadakan wawancara dengan Bapak Rusdi, berikut hasil wawancaranya:

"Saya rasa, sosialisasi yang dilakukan oleh kantor pertanahan pada bulan Februari lalu itu sudah bagus, hanya saja waktunya yang kurang tepat. Kenapa saya mengatakan demikian, karena mereka datang itu sekitar jam 10 pagi. Dimana kita tahu bahwa pada jam itu, masyarakat lagi sibuk di kebun atau sawah mereka. Selain itu, alasan sehingga masyarakat kurang datang mendengarkan sosialisasi karena mereka berfikir lebih baik mereka datang saja nanti di kantor desa atau bertanya ke tetangganya yang sudah tahu. Karena kalaupun mereka datang saat sosialisasi kadang ada yang tidak mereka fahami tapi malu bertanya karena mereka segan dan malu dengan pegawai kantor pertanahan. ,34

Pada hari itu juga, peneliti melakukan wawancara dengan Bapak Akram untuk mengetahui respon masyarakat terhadap sosialisasi yang dilakukan oleh kantor pertanahan:

"Sosialisasi tersebut memang sudah terlaksana, dan saya beserta Bapak Kepala Desa sudah menyampaikan kepada tiap kepala dusun agar memberitahukan kepada seluruh warganya bahwa akan ada sosialisasi dari kantor pertanahan tentang sertipikat murah, tapi yang hadir hanya beberapa orang. Lebih banyak yang tidak respon. Ada yang beralasan bahwa kalaupun mereka datang paling yang disampaikan oleh pegawai kantor pertanahan itu hanya garis-garis besarnya. Mereka tidak menjelaskan secara detail tahap pelaksanaannya kepada masyarakat. Jadi mereka lebih memilih bertanya di kantor desa saja. Dan hampir tiap hari masyarakat datang kesini untuk bertanya. Ada yang belum memahami

\footnotetext{
${ }^{32}$ Saiful (49 tahun), Ketua Adjukasi PTSL, Wawancara, Enrekang, 09 Oktober 2018.

${ }^{33}$ Syafaruddin (56 tahun), Ketua Fisik PTSL, Wawancara, Enrekang, 09 Oktober 2018.

${ }^{34}$ Rusdi (43 tahun), Kepala Desa Lebang, Wawancara, Lebang, 10 Okotober 2018.
} 
Metode Pelayanan Informasi Pensertipikatan Tanah Negara melalui Program Pendaftaran Tanah Sistematis Lengkap di Kantor Pertanahan Kabupaten Enrekang

cara mengisi angket, ada yang belum tahu apa saja berkas yang harus mereka siapkan, macam-macamlah yang mereka tanyakan . "35

Untuk mengetahui tindak lanjut yang dilakukan oleh pihak desa terhadap sosialisasi yang telah dilakukan oleh kantor pertanahan, peneliti kembali mengajukan pertanyaan kepada Bapak Akram:

"Saya meminta kepada semua kepala dusun yang ada di desa Lebang agar melakukan koordinir langsung kepada masyarakat yang ada di dusunnya masing-masing. Di sini ada 4 dusun yaitu dusun Lebang, dusun Bissakan, dusun Garege dan dusun Panette. Dan itu sudah dilakukan oleh kepala dusun." 36

Peneliti lalu melakukan wawancara dengan Bapak Muhammad Arsyad terkait tindak lanjut yang dilakukan:

"Saya melakukan pengumuman di masjid dengan menggunakan mikrofon setiap selesai shalat berjamaah, utamanya kalau selesai shalat magrib. Tetapi karena jarak rumah di sini yang agak berjauhan sehingga pengumuman saya tidak didengar oleh seluruh warga di dusun ini. "37

Pada hari itu juga, peneliti melakukan wawancara dengan salah seorang masyarakat peserta PTSL untuk mengetahui sejauh mana pengetahuan masyarakat tentang kegiatan PTSL:

"Saya tauji, karena pada saat sosialisasi pertama di kantor desa saya datang. Hanya saja banyak yang disampaikan oleh pegawai kantor pertanahan yang tidak saya fahami. Dan saya malu-malu untuk bertanya langsung saat itu. Jadi saya hanya diam-diam dan berfikir nanti sajalah saya datang bertanya ke Pak Desa atau Staf Desa. "38

Hal yang sedikit berbeda diungkapkan oleh Pak Iqbal:

"Awalnya saya tidak tau, karena saya berada di dusun yang jauh dari kantor desa. Dan jaringan telepon juga sangat terbatas. Nanti setelah saya ke kebun dan melihat ada pengukur di tanah dekat kebunku, saya bertanya pada pengukur itu dan saya diberitau bahwa ada program sertipikat murah. Namun karena informasi yang diberikan oleh pengukur itu juga tidak terlalu jelas saya lalu bertanya di kantor desa. Dan saya diberitahu bahwa memang ada dan akan ada sosialisasi dari kantor

${ }^{35}$ Akram Prasetya (37 tahun), Staf Desa Lebang, Wawancara, Lebang, 10 Oktober 2018.

${ }^{36}$ Akram Prasetya (37 tahun), Staf Desa Lebang, Wawancara, Lebang, 10 Oktober 2018. Oktober 2018

${ }^{37}$ Muhammad Arsyad (58 tahun), Kepala Dusun Garege, Wawancara, Lebang, 11

${ }^{38}$ Sulaiman Tonreng (51 tahun), Masyarakat Peserta PTSL, Wawancara, Lebang, 11 Oktober 2018 . 
pertanahan lagi tiga hari kemudian. Sosialisasi kedua itu kalau tidak salah dilaksanakan pada bulan april, saya hadir disitu. "39

Segala kegiatan pasti mempunyai prosedur tertentu yang sudah disusun sebelum kegiatan dimulai. Terkait prosedur untuk menjadi peserta PTSL, peneliti kembali melakukan wawancara dengan Bapak Sulaiman Tonreng:

"Saya faham tapi hanya sedikit. Karena saat pegawai kantor pertanahan mengadakan sosialisasi di kantor desa, mereka tidak menjelaskan secara rinci tentang apa apa yang harus kami siapkan. Mau bertanya juga malu. Jadi saya hanya diam dan menunggu warga lain bertanya. Tapi sampai selesai sosialisasi tidak ada kejelasan yang saya dapat. Atau mungkin ada tapi saya yang tidak dengar atau tidak faham. ",40

Peneliti juga melakukan wawancara dengan Bapak Iqbal:

"Saya kan awalnya tidak tau apa-apa. Nanti di sosialisasi kedua itu baru saya tau dan itupun saya datang agak telat karena jarak rumah saya yang cukup jauh. Dan mengenai persyaratan PTSL, saya tanyakan semua saat itu sama pegawai kantor pertanahan. Dan Alhamdulillah mereka memberikan saya penjelasan. Tetapi setelah itu, saya masih sering ke kantor desa bertanya jika ada yang belum saya ketahui. "4l

Dari hasil wawancara yang telah peneliti lakukan dengan informan, baik itu dengan Pegawai Kantor Pertanahan, Kepala Desa, Staf Desa, Tokoh Masyarakat maupun dengan peserta PTSL maka diketahui bahwa Kantor Pertanahan menggunakan metode informative communication dalam pelayanan informasi tentang PTSL. Metode ini bertujuan untuk mengurangi keragu-raguan dalam hal pengambilan keputusan. Dengan adanya informasi yang diberikan oleh Kantor Pertanahan maka diharapkan akan membantu mengurangi ketidakpastian masyarakat peserta PTSL serta membantu dalam pengambilan keputusan.

Peneliti menganalisa bahwa metode informative communication yang digunakan oleh Kantor Pertanahan kurang efektif, qaulan baliga (ucapan yang sampai pada lubuk hati orang yang diajak bicara) dan qaulan masyura (ucapan yang mudah, yakni mudah dicerna, mudah dimengerti, dan dipahami oleh komunikan) masih belum terlaksana dengan baik. Peneliti mengatakan kurang efektif, tidak qaulan baliga dan tidak qaulan masyura karena dari hasil wawancara diketahui bahwa hanya sedikit masyarakat yang hadir mengikuti sosialisasi, baik sosialisasi pertama maupun sosialisasi kedua. Adapun masyarakat yang datang juga memberikan tanggapan bahwa ketika sosialisasi berlangsung ada beberapa informasi yang disampaikan dan mereka kurang faham tetapi mereka malu bertanya dan memilih diam menunggu peserta lain bertanya.

\footnotetext{
${ }^{39}$ Iqbal (43 tahun), Masyarakat peserta PTSL, Wawancara, Lebang, 11 Oktober, 2018.

${ }^{40}$ Sulaiman Tonreng (51 tahun), Masyarakat Peserta PTSL, Wawancara, Lebang, 11 Oktober 2018.

${ }^{41}$ Iqbal (43 tahun), Masyarakat peserta PTSL, Wawancara, Lebang, 11 Oktober, 2018.
} 
Keberhasilan sebuah kegiatan/ program memang sebagian besar ditentukan oleh informasi. Sehingga penyedia informasi (informan) harus jeli dalam meilih metode/ cara penyampaian infromasi. Kantor Pertanahan Kabupaten Enrekang sebagai penyedia informasi seharusnya jeli melihat kondisi tersebut, dan bisa mencoba metode lain yang lebih efektif, jangan terpaku hanya kepada satu metode saja. Misalnya metode persuasive communication atau metode coersive/instructive communication agar informasi yang akan disampaikan betulbetul bisa sampai kepada masyarakat (komunikan) dan PTSL bisa berjalan sesuai apa yang diharapkan, sehingga bisa memberikan faedah dan manfaat kepada kedua bela pihak, baik bagi Kantor Pertanahan itu sendiri maupun bagi masyarakat.

Peneliti menyimpulkan temuan lapangan dalam tabel berikut:

\section{Efektivitas Metode Pelayanan Informasi}

\begin{tabular}{|c|c|c|}
\hline Indikator & Variabel & Temuan Lapangan \\
\hline $\begin{array}{l}\text { Tingkat } \\
\text { efektivitas } \\
\text { metode } \\
\text { pelayanan } \\
\text { informasi }\end{array}$ & $\begin{array}{l}\text { 1. Jenis metode } \\
\text { yang digunakan } \\
\text { Kantor } \\
\text { Pertanahan } \\
\text { dalam pelayanan } \\
\text { informasi } \\
\text { 2. Alasan } \\
\text { penggunaan } \\
\text { metode } \\
\text { informative } \\
\text { communication } \\
\text { Kendala yang } \\
\text { dihadapi pegawai } \\
\text { Kantor } \\
\text { Pertanahan } \\
\text { dalam pelayanan } \\
\text { informasi dengan } \\
\text { metode la lanjut } \\
\text { informative } \\
\text { communication } \\
\text { 4. Tindak lanjut } \\
\text { Pegawai Kantor } \\
\text { Pertanahan } \\
\text { 5. Respon aparat } \\
\text { Desa dan } \\
\text { masyarakat } \\
\text { peserta PTSL } \\
\text { Tindak lak } \\
\text { aparat Desa } \\
\text { 7. Pengetahuan } \\
\text { dan pemahaman }\end{array}$ & $\begin{array}{l}\text { 1. Kantor Pertanahan menggunakan } \\
\text { metode informative communication. } \\
\text { 2. Masyarakat desa pada umumnya } \\
\text { masih lebih dominan untuk } \\
\text { mengetahui sebuah informasi dari } \\
\text { hasil mendengar. Kalau informasi } \\
\text { disampaikan secara tertulis, } \\
\text { dikhawatirkan masyarakat tidak akan } \\
\text { membaca informasi tersebut, karena } \\
\text { sebagaimana fenomena sekarang } \\
\text { bahawa minat baca masyarakat pada } \\
\text { umunya masih rendah. } \\
\text { 3. Sosialisasi berjalan kurang efektif } \\
\text { karena hanya sedikit masyarakat } \\
\text { yang menghadiri. Mereka agak } \\
\text { susah untuk meluangkan waktu } \\
\text { dengan alasan bahwa mereka } \\
\text { mempunyai kesibukan lain di kebun/ } \\
\text { sawah mereka. Sehingga informasi } \\
\text { yang disampaikan oleh Kantor } \\
\text { Pertanahan tidak merata ke seluruh } \\
\text { masyarakat. } \\
\text { Kantor pertanahan masih melakukan } \\
\text { metode informative communication, } \\
\text { yaitu melakukan sosialisasi lanjutan. } \\
\text { Aparat desa merespon dengan baik. } \\
\text { Kepala desa beserta staf desa } \\
\text { menyampaikan kepada kepala dusun } \\
\text { dan tokoh masyarakat agar } \\
\text { menyampaikan ke seluruh warga di } \\
\text { desa itu untuk menghadiri sosialisasi }\end{array}$ \\
\hline
\end{tabular}




\begin{tabular}{|l|l|l|}
\hline masyarakat & yang akan dilaksanakan oleh kantor \\
& peserta PTSL & yang ada di desa itu kurang respon \\
& & dengan sosialisasi terebut dan hanya \\
& sebagian kecil yang menghadiri \\
& 6. $\begin{array}{l}\text { Mengarahkan kepada seluruh kepala } \\
\text { dusun yang ada di desa Lebang agar } \\
\end{array}$ & melakukan koordinir langsung \\
& dengan masyarakat. Kepala dusun \\
& segera menindaklanjuti dengan \\
& melakukan pengumuman di masjid \\
& setiap selesai shalat berjamaah. \\
& Masyarakat sebagian besar sudah \\
& mengetahui akan adanya PTSL, \\
& hanya saja pemahaman mereka \\
& masih kurang utamanya dalam hal \\
& prosedur dan kelengkapan berkas. \\
\hline
\end{tabular}

\section{PENUTUP}

Berdasarkan pembahasan pada bab sebelumnya, maka hasil penelitian dapat ditarik kesimpulan bahwa tingkat efektivitas metode informative communication yang digunakan oleh Kantor Pertanahan kurang efektif, qaulan baliga (ucapan yang sampai pada lubuk hati orang yang diajak bicara) dan qaulan masyura (ucapan yang mudah, yakni mudah dicerna, mudah dimengerti, dan dipahami oleh komunikan) masih belum terlaksana dengan baik. Peneliti mengatakan kurang efektif, tidak qaulan baliga dan tidak qaulan masyura karena dari hasil wawancara diketahui bahwa hanya sedikit masyarakat yang hadir mengikuti sosialisasi, baik sosialisasi pertama maupun sosialisasi kedua. Adapun masyarakat yang datang juga memberikan tanggapan bahwa ketika sosialisasi berlangsung ada beberapa informasi yang disampaikan dan mereka kurang faham tetapi mereka malu bertanya dan memilih diam menunggu peserta lain bertanya.

Berdasarkan kesimpulan di atas, maka dapat disampaikan implikasinya bahwa Kantor Pertanahan Kabupaten Enrekang sebagai penyedia informasi seharusnya jeli melihat kondisi pada masyarakat, dan bisa mencoba metode lain yang lebih efektif, jangan terpaku hanya kepada satu metode saja. Misalnya metode persuasive communication atau metode coersive/instructive communication agar informasi yang akan disampaikan betul-betul bisa sampai kepada masyarakat (komunikan) dan PTSL bisa berjalan sesuai apa yang diharapkan, sehingga bisa memberikan faedah dan manfaat kepada kedua bela pihak, baik bagi Kantor Pertanahan itu sendiri maupun bagi masyarakat. 


\section{DAFTAR PUSTAKA}

AW, Suranto, Komunikasi Efektif Untuk Mendukung Kinerja Perkantoran, 2006, (http://www.google.com/komunikasi/20018).

Hanafi, Abdillah, Memahami Komunikasi Antar Manusia. Surabaya: Usaha Nasional, tt..

http://el-syahida.blogspot.com/2014/06/qoulan-baliigho-dalam-al-quran.html (akses pada tanggal 22 September 2018)

http://romeltea.com/komunikasi-islam-makna-dan-prinsip/ (akses pada 21 September 2018).

http://situliatsitucoment.blogspot.com/2010/02/informative-communicationkomunikasi.html, diakses pada tanggal 3 Oktober 2018.

http://www.uky.edu/ drlane/capstone/persuasion/, diakses pada tanggal 3 Oktober 2018.

Munawwir, Ahmad Warson, Kamus Al-Munawwir. Edisi II, Cet. XXV; Surabaya: Pustaka Progressif, 2002.

http://ganiasmoro.blogspot.co.id/2012/03/definisi-macam-macammetode_2144.html, (akses 22 Agustus 2018).

Kementerian Agama RI. Al-Qur'an dan Terjemahnya. Bogor: Dharma Art, 2007.

Pusat Bahasa Departemen Pedidikan Nasional Republik Indonesia, Kamus Besar Bahasa Indonesia, 2012.

Rakhmat, Jalaluddin. Psikologi Komunikasi. Bandung: Remaja Rosdakarya, 1993.

Shihab, Quraish . Tafsir al-Misbah. Jilid II; Jakarta: Lentera Hati, 2000.

Sugiyono. Metode Penelitian Pendidikan Kuantitatif, Kualitatif R\&D. Cet. 4; Bandung: Alfabeta, 2008. 